\title{
RESEARCH AND APPLICATION OF REMOTE SENSING AND GIS TECHNOLOGIES IN DETERMINING AND FORECASTING LAND USE CHANGES BY MARKOV CHAIN IN Y YEN DISTRICT - NAM DINH PROVINCE
}

\author{
Giang Thi Le, PhD \\ Faculty of Land Management \\ Vietnam National University Agriculture, Trau Quy, Gia Lam, Hanoi \\ e-mail:ducmini@yahoo.com

\section{Thuan Duc Nguyen} \\ Faculty of Land Management \\ Vietnam National University Agriculture, Trau Quy, Gia Lam, Hanoi \\ e-mail:nguyenducthuan_mdc@yahoo.com \\ Vinh Quoc Tran \\ Faculty of Land Management \\ Vietnam National University Agriculture, Trau Quy, Gia Lam, Hanoi \\ e-mail: tqvinh@vnau.edu.vn
}

\begin{abstract}
The land's natural resources are invaluable and a requisite for the existence and development of humans and other organisms on Earth. In recent years, under the strong impact of new directions in economic and social development, the demand for land has been increasing. The percentage of land used for residential living, transportation, irrigation and infrastructure tends to increase, while the share of agricultural land is continuously decreasing. Consequently, the allocation and efficient use of land is one of the most important concerns in order to enable sustainable development, environmental protection and ecology. Therefore, research to determine the volatility and changing trends in land use is necessary. This study uses remote sensing and GIS technology, combined with the Markov Chain to determine variation and forecast the changes in land use in the Y Yen district of the Nam Dinh province of Vietnam. This will create a basis for helping land managers grasp the situation in local land use management.
\end{abstract}

Keywords: ErDAS, GIS, MARKOV CHAIN, Remote Sensing, Land, Land use change.

JEL Classification: R14

Citation: Thi Le G., Duc Nguyen T., Quoc Tran V., 2016, Research and Application of Remote Sensing and GIS Technologies in Determining and Forecasting Land Use Changes by Markov Chain in Y Yen District Nam Dinh Province, Real Estate Management and Valuation, Vol. 24, No. 3, pp. 27-39.

DOI: 10.1515/remav-2016-0019

\section{Introduction}

Determining the volatility and trends in land use is a pressing problem that has arisen in consequence of the intense development process of Vietnam. Currently, information technology is continuously developing, facilitating the solving of complex social economic problems of the country in general, 
and land management sectors in particular. Remote sensing technology brings us sources of information and data from satellite images of increasing resolution, a large number of spectral channels, short iteration cycles and vast space cover, faithfully reflecting the Earth's surface at the time of shooting. In addition, combined with the high processing capabilities and powerful data analysis of GIS technology, it creates a useful tool for studying the volatilities and management of land resources. Moreover, the support of the Markov Chain can be useful in the basic assessment of trends in land use. This new method adopted by many of technologically advanced countries in the world, provides better efficiency as compared to traditional methods, allowing for managing and updating revised land information in a quickly and timely manner.

The Y Yen district in Nam Dinh Province has a total natural land area of 24,129.74 hectares (2013). In recent years, under the strong impact of the new directions in economic and social development, the demand for land used for residential purposes, transportation, irrigation, and infrastructure has had a tendency to increase, with the opposite holding true for agricultural land. Therefore, the suitable allocation and efficient use of land are major issues that the government and local authorities must cope with. In light of the above, we have conducted a study on: Research and applications of remote sensing and GIS technologies in determining volatility and forecasting the changes in land use by Markov Chain in Y Yen district - Nam Dinh province.

\section{Research methodology}

\subsection{Method of supervised classification}

The method of supervised classification is one in which the classification criteria are established based on the sample area, and decisions are made based on appropriate algorithms to label each pixel corresponding to a specific land use. The sample areas are the regions of the image corresponding to each kind of land use that people know the spectral characteristics of. Based on data collected in each sample area, statistical parameters are determined. Then, the classification criteria are used in the process of appointing the pixels to particular categories (Asian Association on Remote Sensing 2014).

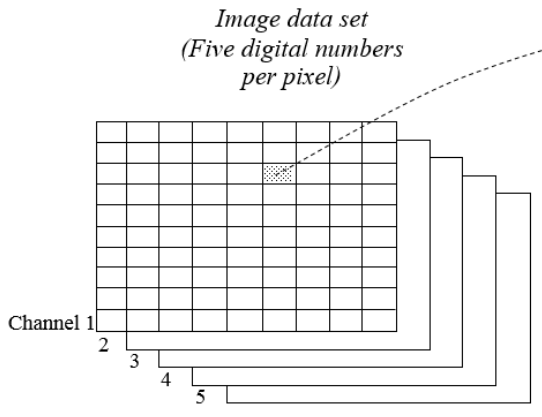

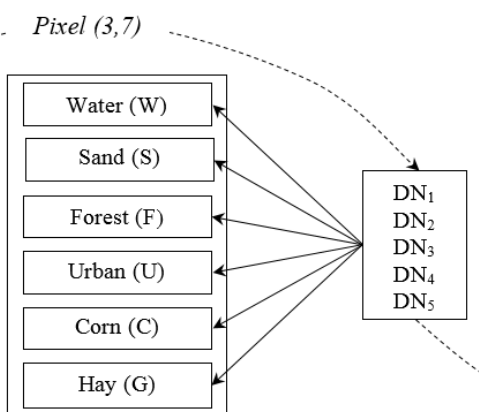

(1) Training stage

Collect numerica

from training

areas on spectral response patterns of land cover
(2) Classification stage Compare each unknown pixel to spectral patterns assign to most similar category

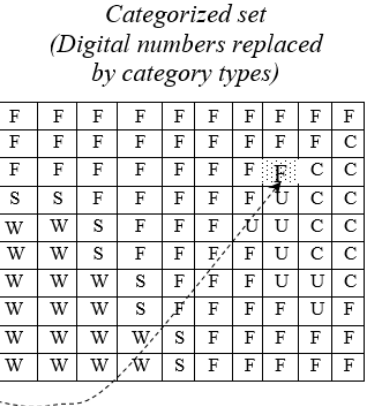

(3) Output stage

Present results: Maps; Tables of area data; Digital data files

Fig. 1: Method of supervised classification. Sources: NGUYEN KHAC THOI et al. (2011).

In this study, the method of supervised classification according to the algorithm of maximum likelihood was chosen to categorize the image (maximum likelihood) (NORRIS 1998):

$$
g_{1}(x)=1 n p\left(\omega_{1}\right)-\frac{1}{2} 1 n\left|z_{1}\right|-\frac{1}{2}\left(x-m_{1}\right)^{2} \sum_{1}^{-1}\left(x-m_{1}\right)
$$

where:

i - object of classification,

x - number of spectral channels,

$p\left(\omega_{i}\right)$ - probability value occurring when object $\omega \mathrm{i}$ is the same as the others,

$\left|\Sigma_{\mathrm{i}}\right| \quad$ - covariance matrix of object $\omega \mathrm{i}$,

$\Sigma_{\mathrm{i}-1} \quad$ - inverse matrix of object $\omega \mathrm{i}$,

$\mathrm{m}_{\mathrm{i}} \quad$ - values of changing spectral vector. 
Classification by means of the maximum likelihood method assuming that the statistics of each class in each image channel is dispersed in a normal way, with the method taking into account the possibility of a pixel belongings to a certain class to increase the differences between the land uses. If a probability threshold is not chosen, it must classify all pixels. Each pixel is assigned to the class with the highest probability. By this method, the spectral channels follow normal distribution and the pixels are classified in the class that has the highest probability. This is the most accurate method of classification, but it takes time to calculate and relies on the normal distribution of data. The method comprises the following steps (RICHARDS 1999):

- Identify the types: Because Satellite image data always factually and objectively reflects the surface of the Earth at the time of shooting, this results is a land use map. In order to construct a training set, it is first necessary to determine the type of land use in the study area.

- Selection of features: The features here include spectral and structural features. This selection is very important as it makes it possible to distinguish the object classes.

- Selection of the sample areas: The selection of sample areas is crucial to the classification results.

To ensure accuracy in choosing appropriate sample areas, attention should be paid to the following requirements:

- The number of the sample areas for each type of object must be appropriate. Too few sample areas will not guarantee accuracy, whereas too many sample areas will increase the volume of calculations, sometimes distorting their results,

- The area of the sample should be sufficiently large, and not located near the border between different object classes,

- The selected sample should be presented for the classified object and evenly distributed across the study area,

- Calculation of sample statistical indicators: After choosing the sample, it is necessary to calculate the statistical indicators and the difference between samples (WANG et al. 2009).

Assessing the precision of the sample file: each classification sample will be calculated to compare the difference with the remaining samples.

Assessing the accuracy of the image classification: The accuracy of the image classification depends not only on the accuracy of the sample areas, but also on the density and the distribution of sample plots. The nature of the errors made during the classification process is assessed based on the Kappa (к) index. This index ranges from 0 to 1 , indicating the proportional reduction in error, and is performed by completely random classification (CHUVIECO 2016).

$$
\kappa=\frac{N \sum_{i=1}^{r} x_{i i}-\sum_{i=1}^{r}\left(x_{i+} \cdot x_{+i}\right)}{N^{2}-\sum_{i=1}^{r}\left(x_{i+} \cdot x_{+i}\right)}
$$

where:

$\mathrm{N} \quad$ - total number of sampling points,

$\mathrm{r} \quad$ - the number of classified object classes,

$x_{i i} \quad$ number of actual sampling points in the $1^{\text {st }}$ class,

$x_{i+} \quad-$ total number of points in the $i^{\text {th }}$ class of the sample,

$\mathrm{x}_{+\mathrm{i}} \quad$ - total number points in the $\mathrm{i}^{\text {th }}$ class after classification.

\subsection{Method of determining the volatility of land use by comparison after classification}

The nature of this approach is that we obtain two maps of land use from the results of image classification at two different times. We then overlay these two maps of land use to build the volatility map (Figure 2). These maps can take the form of raster or vector maps.

The comparison method after classification is the most widely used method, as it is very simple, and easy to understand and implement. After the 2 satellite images are geometrically corrected, independent classification will be implemented to build two land use maps. These two maps are overlaid by comparing pixels to form a volatile matrix (CROSETTO, MROZ 1998).

According to J. Jensen, the advantage of this method is that it shows any kind of change from one kind of land use to others; its disadvantage is that classification has to be carried out independent of remote sensing images. Therefore, its precision depends on the accuracy of each kind of classification 
and is normally not very high because errors in the classification of each photo continue to remain in the volatile map (JENSEN 1996; PONTIUS, PeTROVA 2010).

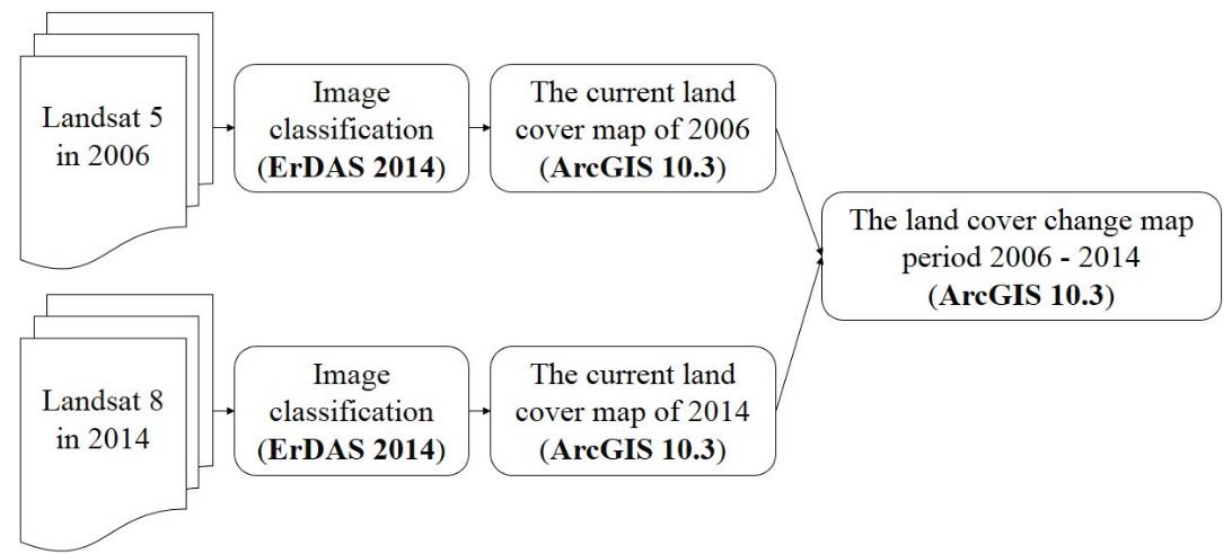

Fig. 2. Comparison method after classification. Sources: own study.

\subsection{Method of determining the trend in land use changes by Markov Chain}

Using the Markov Chain forecasts trends in changes of land use over a certain period of time. The Markov Chain model is used to determine the ability to change land use based on its evolution and the factors affecting such change. General modeling is as follows:

$$
\left(\begin{array}{c}
\text { The proportion of } \\
\text { land use in the } \\
\text { 1st perlod }
\end{array}\right) \times\left(\begin{array}{c}
\text { Matrix of change } \\
\text { in land use between } \\
\text { the 1st and 2nd perlod }
\end{array}\right)=\left(\begin{array}{c}
\text { The proportion of } \\
\text { land use types } \\
\text { in the 2nd perlod }
\end{array}\right)
$$

and can be rewritten as a generalization of the matrix (NORRIS 1998):

$$
[\mathrm{V} 1, \mathrm{~V} 2, \mathrm{~V} 3]_{1} \times\left[\begin{array}{l}
\gamma_{11}, \gamma_{12}, \gamma_{13} \\
\gamma_{21}, \gamma_{22}, \gamma_{28} \\
\gamma_{81}, Y_{82}, Y_{88}
\end{array}\right]=[\mathrm{V} 1, V 2, V 3]_{2}
$$

In which, $\mathrm{Y}_{\mathrm{if}}$ is the probability of change that is determined from the overlay of the land use maps at different times. The above model can be used to predict the distribution of land use in the future.

\subsection{The process of identifying and forecasting the volatility of land use change}

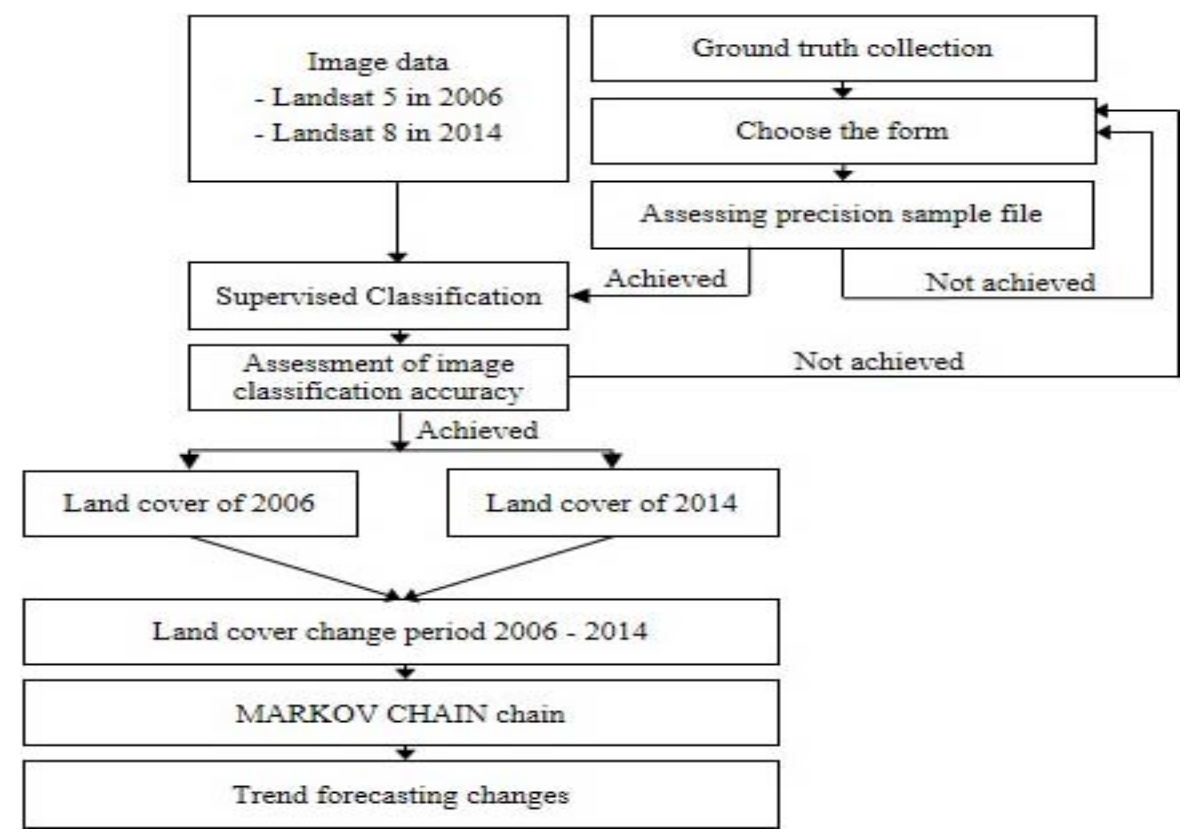

Fig. 3: The process of identifying and forecasting the volatility of land use change. Sources: own study. 


\section{Results}

\subsection{Introduction of Landsat satellite system}

Landsat is a series of American experiment satellites managed by the NASA (National Aeronautics and Space Administration) aerospace agency. This is a marginal orbit satellites system (their orbital plane angle compared to the equatorial plane is $98.2^{\circ}$ ), initially named ERST (Earth Remote Sensing Satellite); 2 years after the launch of ERST - 1, its name changed to Landsat, and then to Landsat - TM and Landsat - ETM (MRÓz 2002).

The first Landsat satellite was launched into orbit on the $23^{\text {rd }}$ July, 1972 and retired on the $1^{\text {st }}$ June, 1978 with the name of Landsat 1. As of now, there have been 8 generations of Landsat. Landsat images have been applied in many fields of research, from status research to monitoring land use change, and are characterized by popularity and low cost (KOK, WINOGRAD 2002).

The Landsat satellite system

Table 1

\begin{tabular}{llll}
\hline Satellite & Launch & Decommissioned & Sensor \\
\hline Landsat 1 & 23.07 .1972 & 06.01 .1978 & MSS - TM \\
\hline Landsat 2 & 22.01 .1975 & 25.02 .1982 & MSS - TM \\
\hline Landsat 3 & 05.03 .1978 & 31.03 .1983 & MSS - TM \\
\hline Landsat 4 & 16.07 .1982 & 15.06 .2001 & MSS - TM \\
\hline Landsat 5 & 01.03 .1984 & 08.1995 & MSS - TM \\
\hline Landsat 6 & 05.03 .1993 & Failure lunch & TM/ ETM \\
\hline Landsat 7 & 15.04 .1999 & Active & ETM + \\
\hline Landsat 8 & 11.02 .2013 & Active & OLI - TIRS \\
\hline
\end{tabular}

Sources: own study.

\subsection{Research data}

Satellite images used in the study are downloaded directly from the site (http:/ / earthexplorer.usgs.gov/) of the United States Geological Survey (USGS) for the Y Yen District of Nam Dinh Province, including:

Landsat 5 data with 30 meters resolution for spectral channels 1,2, 3, 4, 5, 7, and 60 meters for the $6^{\text {th }}$ spectral channel received on the $6^{\text {th }}$ November, 2006, with the Path number of 126 and Row number of 46 .

Landsat 8 Data with 30 meters resolution for spectral channels 1, 2, 3, 4, 5, 6, 7 and 9, 15 meters for the $8^{\text {th }}$ channel, and 100 meters for the $10^{\text {th }}$ and $11^{\text {th }}$ spectral channels received on $11^{\text {th }}$ October, 2014, with the Path number of 126, and Row number 46.

Collected satellite data

Table 2

\begin{tabular}{llll}
\hline Satellite & Data name & File date & Path / Row \\
\hline Landsat 5 & LT51260462006310BJC00 & 06.11 .2006 & $126 / 46$ \\
\hline Landsat 8 & LC81260462014284LGN00 & 11.10 .2014 & $126 / 46$ \\
\hline
\end{tabular}

Sources: own study.

Table 3

Comparison of the characteristic spectral channels of an image between Landsat 5 and Landsat 8

\begin{tabular}{|c|c|c|c|}
\hline \multirow[t]{2}{*}{ Landsat 5 TM } & & \multicolumn{2}{|c|}{ Landsat 8 OLI and TIRS } \\
\hline & & 30m Coastal/ Aerosol & $0.435-0.451 \mu \mathrm{m}$ Band 1 \\
\hline Band 1 30m Blue & $0.441-0.514 \mu \mathrm{m}$ & 30m Blue & $0.452-0.512 \mu \mathrm{m}$ Band 2 \\
\hline Band 2 30m Green & $0.519-0.601 \mu \mathrm{m}$ & 30m Green & $0.533-0.590 \mu \mathrm{m}$ Band 3 \\
\hline Band 3 30m Red & $0.631-0.692 \mu \mathrm{m}$ & $30 \mathrm{~m}$ Red & $0.636-0.673 \mu \mathrm{m}$ Band 4 \\
\hline Band 4 30m NIR & $0.772-0.898 \mu \mathrm{m}$ & $30 \mathrm{~m}$ NIR & 0.851-0.879 $\mu \mathrm{m}$ Band 5 \\
\hline Band 5 30m SWIR-1 & $1.547-1.749 \mu \mathrm{m}$ & 30m SWIR-1 & 1.566-1.651 $\mu \mathrm{m}$ Band 6 \\
\hline
\end{tabular}




\begin{tabular}{|c|c|c|c|c|}
\hline Band 6 60m TIR & $10.31-12.36 \mu \mathrm{m}$ & 100m TIR-1 & $10.60-11.19 \mu \mathrm{m}$ & Band 10 \\
\hline & & 100m TIR-2 & $11.50-12.51 \mu \mathrm{m}$ & Band 11 \\
\hline \multirow[t]{3}{*}{ Band 7 30m SWIR-2 } & $2.064-2.345 \mu \mathrm{m}$ & $30 \mathrm{~m}$ SWIR-2 & $2.107-2.294 \mu \mathrm{m}$ & Band 7 \\
\hline & & 15m Pan & $0.503-0.676 \mu \mathrm{m}$ & Band 8 \\
\hline & & 30m Cirrus & $1.363-1.384 \mu \mathrm{m}$ & Band 9 \\
\hline
\end{tabular}

Sources: own study.

\subsection{Results and Discussion}

\subsubsection{Creation of interpreted keys}

For any kind of image interpretation, it is necessary to determine the type of land use in the study area. Based on the current use of land, material characteristics of satellite images and image resolution, the authors distinguished 4 types of land use presented in the classification tables (Table 4). Based on these, the keys for interpretation were constructed with the support of handle GPS during field research (Table 5) (SOHL, SAYLER 2008).

Table 4

Classification of land use types in Y Yen district

\begin{tabular}{ll}
\hline Land use type & Description \\
\hline Agriculture & Paddy rice; Annual crops, Pedestrial crops; $\ldots$ \\
\hline Building & $\begin{array}{l}\text { Residential land; land used for } \\
\text { transportation; land in industrial zones; Land } \\
\text { for construction of offices and public service } \\
\text { institutions; land for cemeteries, graveyards; } \\
\text { other building land }\end{array}$ \\
\hline Water surface & $\begin{array}{l}\text { Land with rivers, streams, canals, and } \\
\text { specialized water surfaces. }\end{array}$ \\
\hline Unused land & Unused land. \\
\hline
\end{tabular}

Sources: own study.

Sample satellite image interpretation Landsat 5-2006 and Landsat 8-2014

Table 5

\begin{tabular}{l|ccc}
\hline Land cover type & Image 2006 & Image 2014 & Field image \\
\hline Agriculture & & & \\
\hline & & & \\
\hline Building & & & \\
\hline & & & \\
\hline Water surface & & & \\
\hline & & & \\
\hline
\end{tabular}

Sources: own study.

\subsubsection{Construction and assessing the accuracy of sample files}

With the support from the field research and survey data, land use maps have been delineated directly onto the image with 4 types of selected land use (Figure 4). 


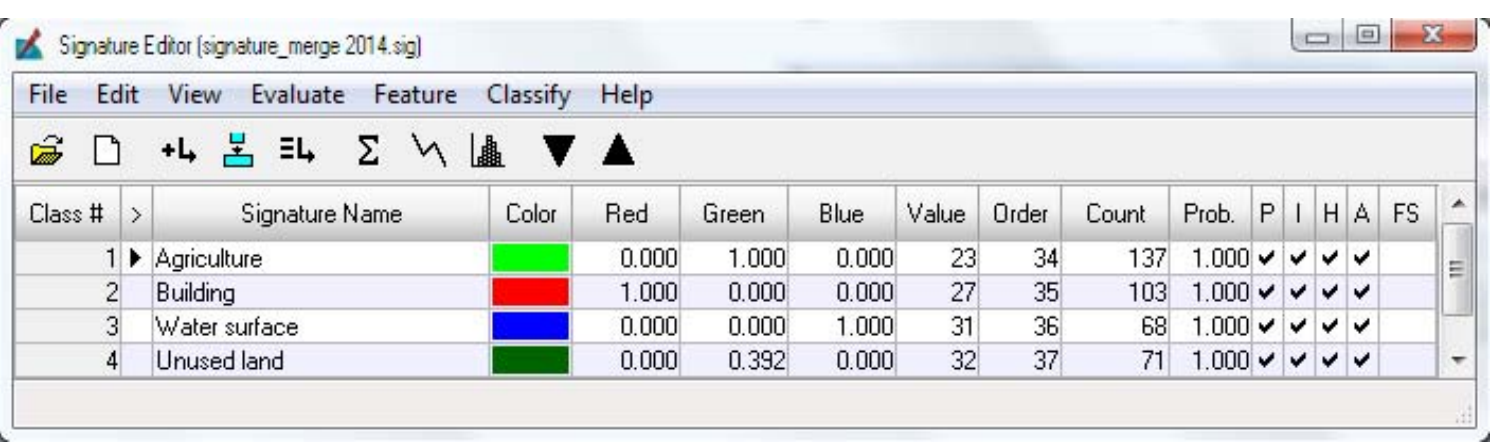

Fig. 4: Sample Files of Landsat 8-2014. Sources: own study.

Based on the characteristics of reflected spectral energy of the object selected in the sample files, the differences between samples were calculated, and the feature space method was selected for analysis (Spectrum Space change). The results showed that the fewer techniques of intereferometry are used, the higher the accuracy. The results also reflected that the accuracy of the selected sample files for both images are good (Figure 5).

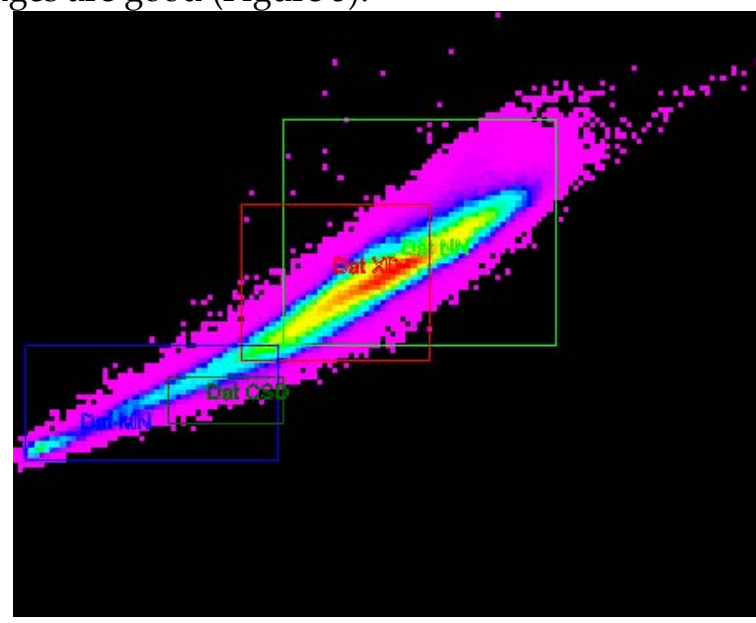

(a)

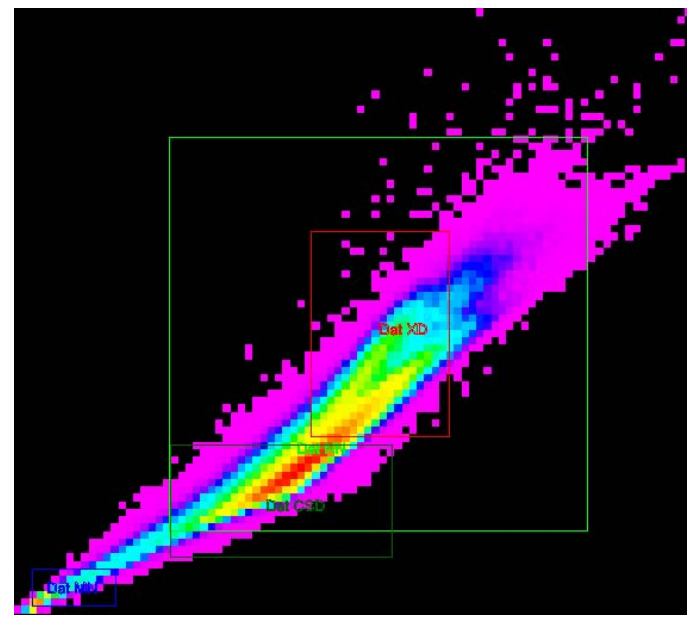

(b)

Fig. 5: Results of evaluating the accuracy of Landsat 5 - 2006 (a) and Landsat 8 - 2014 (b) sample files image. Sources: own study.

\subsubsection{Classification and assessing the accuracy of its results}

In the method of supervised classification under the maximum likelihood algorithm (Maximum likelihood), the obtained results were land use maps for 2006 and for 2014 (Figure 6), and an interference filter used on the obtained classification results to dissolve the pixels (RAY, PIJANOWSKI 2010).

To assess the accuracy of image classification results for image classification in 2014, we used handheld measuring GPS equipment for field control with 100 GPS points; for image classification in 2006, the authors combined field surveys and land use maps from 2005 with 103 points to evaluate the accuracy. The evaluation process was done automatically using ERDAS 2014 software and achieved good results (SOHL et al. 2008; VOGELMANN, TOLK, ZHU 2009).

- The accuracy of Landsat 5-2006 image classification results was $97.00 \%$, and the Kappa index was 0.9575 (Figure 7 (a)),

- Accuracy of Landsat 8-2014 image classification results was $85.44 \%$, and the Kappa index was 0.7914 (Figure 7 (b)). 


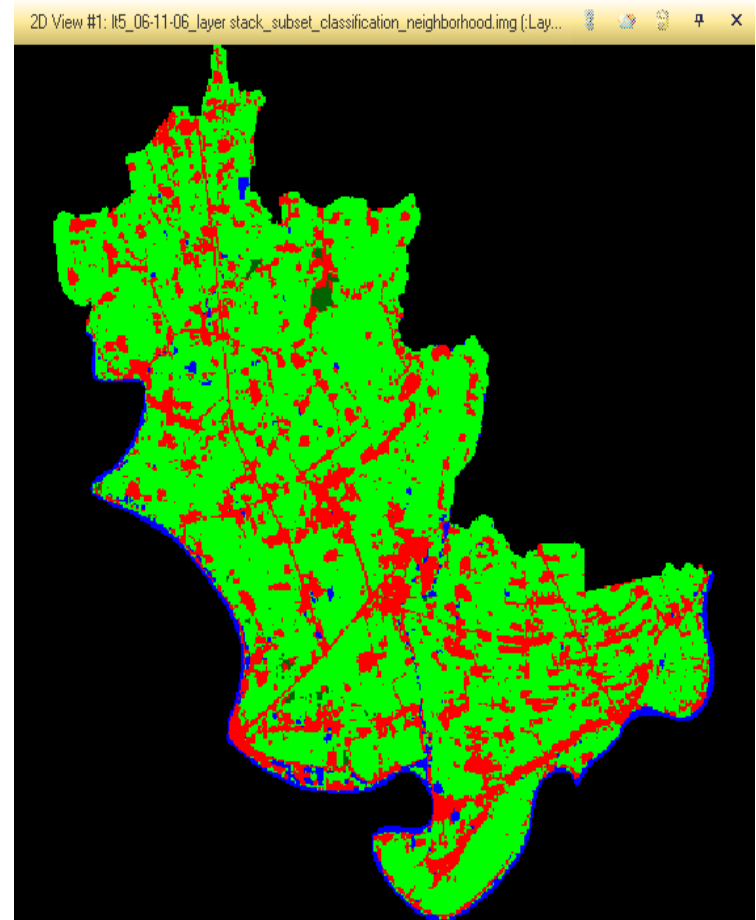

(a)

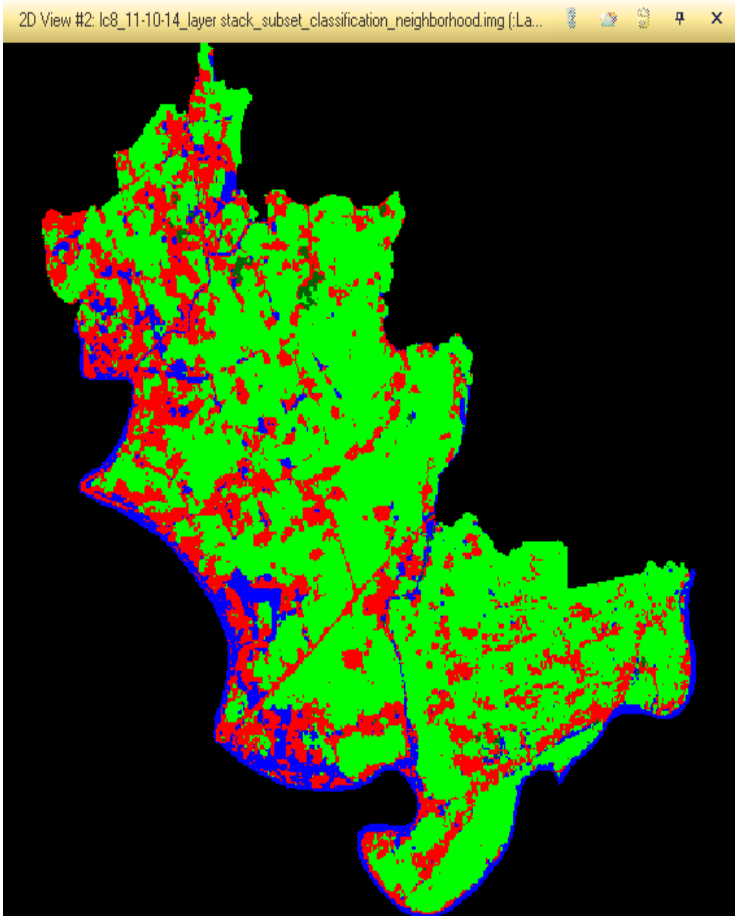

(b)

Fig. 6: Results of Landsat 5 - 2006 (a) and Landsat 8 - 2014 (b) image classification. Sources: own study.

(a)

\section{CLASSIFICATION ACCURACY ASSESSMENT REFORT}

EFROR MATRIX

\begin{tabular}{|c|c|c|c|c|c|c|}
\hline \multirow[b]{2}{*}{ Classified Data } & \multirow[b]{2}{*}{ Agriculture } & \multicolumn{5}{|c|}{ Reference Data } \\
\hline & & Building & Water surface & Unused land & $\mathrm{R} \square \mathrm{W}$ & Total \\
\hline Agriculture & 34 & 0 & 2 & 1 & & 37 \\
\hline Building & 0 & 35 & 0 & 0 & & 35 \\
\hline Water surface & 0 & 0 & 17 & 0 & & 17 \\
\hline Unused land & 0 & 0 & 0 & 11 & & 11 \\
\hline Column Total & 34 & 35 & 19 & 12 & & 100 \\
\hline
\end{tabular}

----- End of Error Matrix -----

ACCURACY TOTALS

$\begin{array}{rrr}\text { Class } & \text { Reference } & \text { Classified } \\ \text { Nanit } & \text { Totals } & \text { Totals } \\ \text { Agriculture } & 34 & 37 \\ \text { Building } & 35 & 35 \\ \text { Water surface } & 19 & 17 \\ \text { Unused land } & 12 & 11 \\ \text { Totals } & 100 & 100\end{array}$

Overall Classification Acouracy = $9700 \%$

\begin{tabular}{rrr} 
Number & Producers & \multicolumn{1}{l}{ Users } \\
Correct & Acouracy & \multicolumn{1}{c}{ Acouracy } \\
- & $-1--$ \\
34 & $100.00 \%$ & $91.89 \%$ \\
35 & $100.00 \%$ & $100.00 \%$ \\
17 & $89.47 \%$ & $100.00 \%$ \\
11 & $91.67 \%$ & $100.00 \%$ \\
97 & &
\end{tabular}

KAFPA $\left(\mathrm{K}^{\wedge}\right)$ STATISTICS

$\begin{array}{cc}\text { Overall Kappa Statistics }= & 0.9575 \\ \text { Conditional Kappa for each Categary } \\ \text {-0lass Name } & \text { Kappa } \\ \text { Cariculture } & -9771 \\ \text { Building } & 0.871 .0000 \\ \text { Water surface } & 1.0000 \\ \text { Unused land } & 1.0000\end{array}$

Unused land 
(b)

\section{CLASSIFICATION ACCURACY AGSESSMENT REPORT}

ERFOR MATRIX

\begin{tabular}{|c|c|c|c|c|c|}
\hline \multirow[b]{2}{*}{ Classified Data } & \multirow[b]{2}{*}{ Agriculture } & \multicolumn{2}{|c|}{ Reference Data } & \multirow[b]{2}{*}{ Unused land } & \multirow[b]{2}{*}{ Tatal } \\
\hline & & Building & Water surface & & \\
\hline Agricul ture & 32 & 3 & 3 & 1 & 39 \\
\hline Building & 2 & 33 & 4 & 2 & 41 \\
\hline Water surface & 0 & 0 & 14 & 0 & 14 \\
\hline Unused land & 0 & 0 & 0 & 9 & 9 \\
\hline Columin Total & 34 & 36 & 21 & 12 & 103 \\
\hline
\end{tabular}

- End of Error Matrix -----

ACCURACY TOTALS

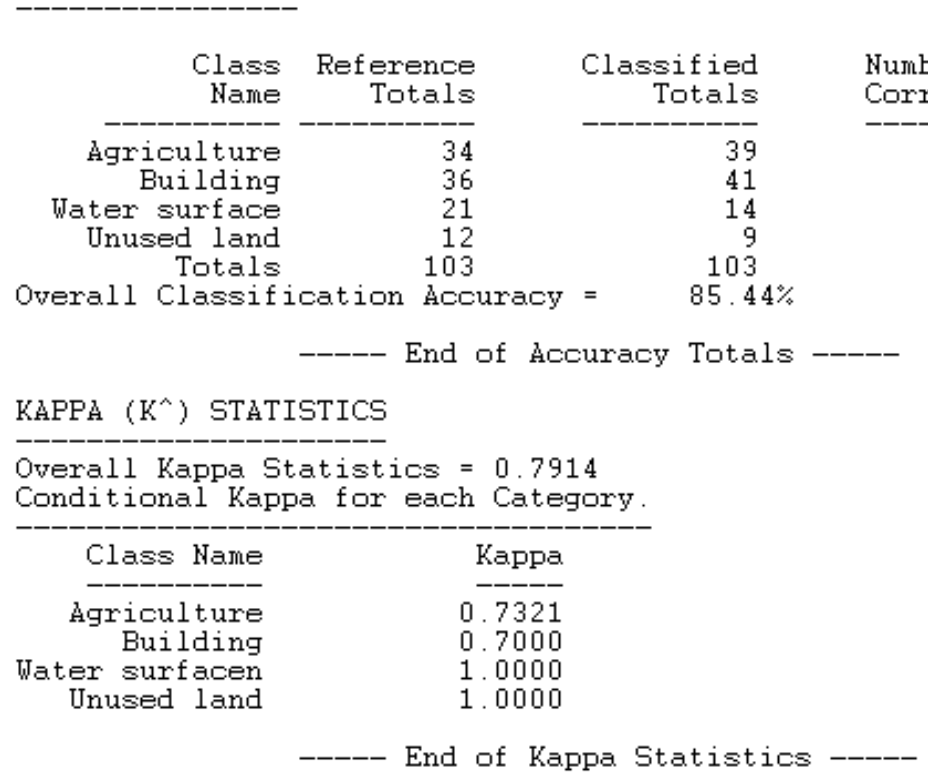

Fig. 7: Evaluation results of Landsat 5 - 2006 (a) and Landsat 8 - 2014 (b) image classification accuracy. Sources: own study.

\section{Transfer from image classification into vector}

The final step to forming maps of land use based on remote sensing and GIS was to transfer the images from raster to vector formats (Figure 8). The main purpose of this is to integrate remote sensing and GIS.

Table 6

Area statistics by types of land use

\begin{tabular}{|c|c|c|c|c|c|}
\hline \multirow{2}{*}{ Land use type } & \multicolumn{2}{|l|}{ Year 2006} & \multicolumn{2}{|l|}{ Year 2014} & \multirow[t]{2}{*}{$\begin{array}{l}\text { Increase (+) } \\
\text { Reduction (- }\end{array}$} \\
\hline & $\begin{array}{l}\text { Area } \\
\text { (ha) }\end{array}$ & $\begin{array}{l}\text { Percentage } \\
(\%)\end{array}$ & $\begin{array}{c}\text { Area } \\
\text { (ha) }\end{array}$ & $\begin{array}{l}\text { Percentage } \\
(\%)\end{array}$ & \\
\hline Agriculture & $16,516.39$ & 68.45 & $15,970.68$ & 66.19 & -545.71 \\
\hline Building & $4,921.43$ & 20.40 & $5,755.79$ & 23.85 & +834.36 \\
\hline Water surface & $2,471.74$ & 10.24 & $2,190.34$ & 9.08 & -281.40 \\
\hline Unused land & 219.05 & 0.91 & 211.80 & 0.88 & -7.25 \\
\hline Total & $24,128.61$ & 100 & $24,128.61$ & 100 & \\
\hline
\end{tabular}

\section{Determination of land use change}

Analyzing the land use change should be based on the pivot table between various types of land use, especially land designated for construction. The Union Function was used to define the change of land 
use in a given area by overlaying the two land use maps, i.e. from 2006 and 2014, to recognize the change in the area of land use (Figure 9), and the Tabulate Area function applied to build the pivot table cycle between various types of land use (Table 7); the results of volatility have been presented in Figure 10 (PONTIUS, PETROVA 2010).

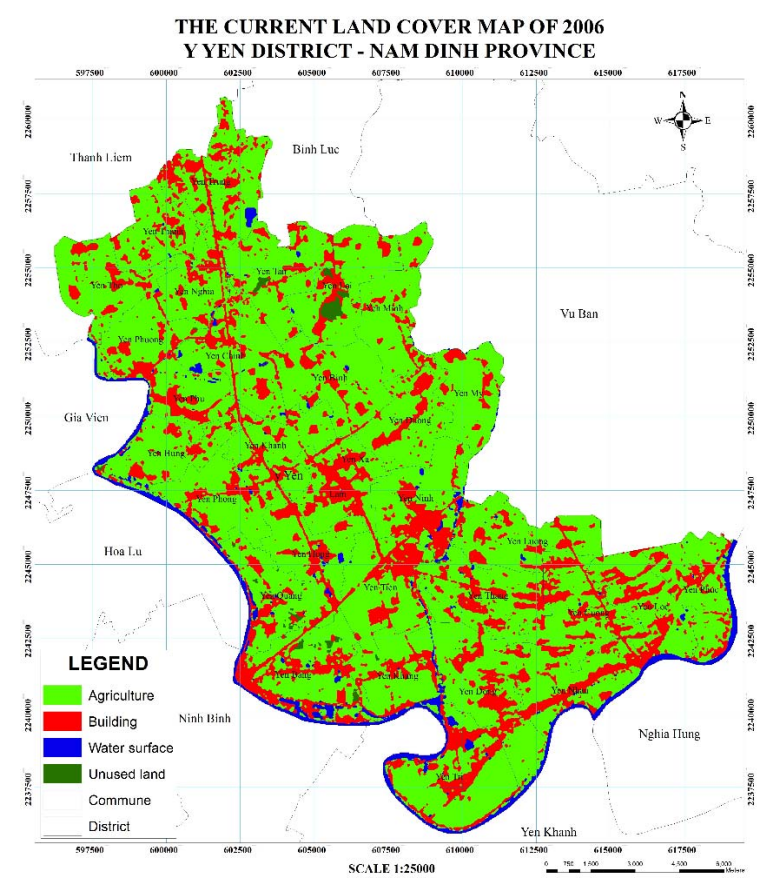

(a)

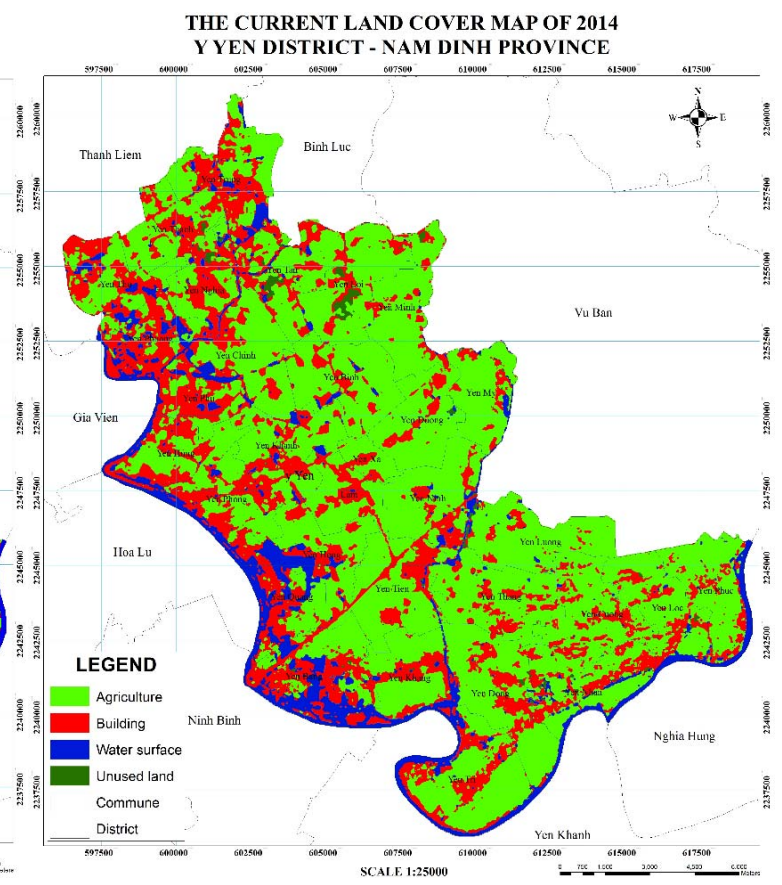

(b)

Fig. 8: Results of Landsat 5 - 2006 (a) and Landsat 8 - 2014 (b) image classification accuracy assessment. Sources: own study.

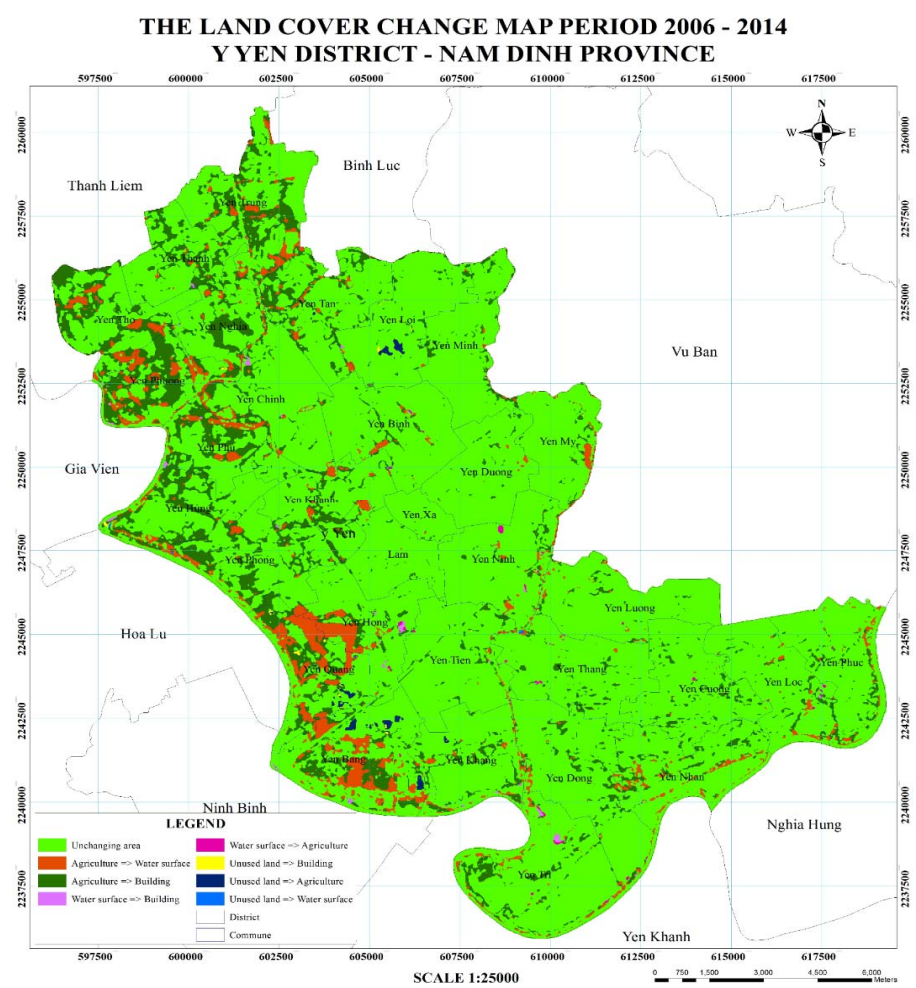

Figure 9: Results of Landsat 5 - 2006 (a) and Landsat 8 - 2014 (b) image classification accuracy assessment. Sources: own study. 
Chart of changes in land use over 2006 - 2014 (Unit: ha)

\begin{tabular}{llllll}
\hline Land use type & Agriculture & Building & $\begin{array}{l}\text { Water } \\
\text { surface }\end{array}$ & $\begin{array}{l}\text { Unused } \\
\text { land }\end{array}$ & Total - 2014 \\
\hline Agriculture & $\mathbf{1 5 , 8 1 6 . 3 9}$ & 0 & 153.00 & 1.29 & $15,970.68$ \\
\hline Building & 501.65 & $\mathbf{4 , 9 2 1 . 4 3}$ & 329.65 & 3.06 & $5,755.79$ \\
\hline Water surface & 198.35 & 0 & $\mathbf{1 , 9 8 9 . 0 9}$ & 2.90 & $2,190.34$ \\
\hline Unused land & 0 & 0 & 0 & $\mathbf{2 1 1 . 8 0}$ & 211.80 \\
\hline Total - 2006 & $16,516.39$ & $4,921.43$ & $2,471.74$ & 219.05 & $\mathbf{2 4 , 1 2 8 . 6 1}$ \\
\hline Increase & 154.29 & 834.36 & 201.25 & 0 & $1,189.90$ \\
\hline Reduction & 700.00 & 0 & 482.65 & 7.25 & $1,189.90$ \\
\hline Land use change & $\mathbf{- 5 4 5 . 7 1}$ & $\mathbf{+ 8 3 4 . 3 6}$ & $\mathbf{- 2 8 1 . 4}$ & $\mathbf{- 7 . 2 5}$ & \\
\hline
\end{tabular}

Sources: own study.

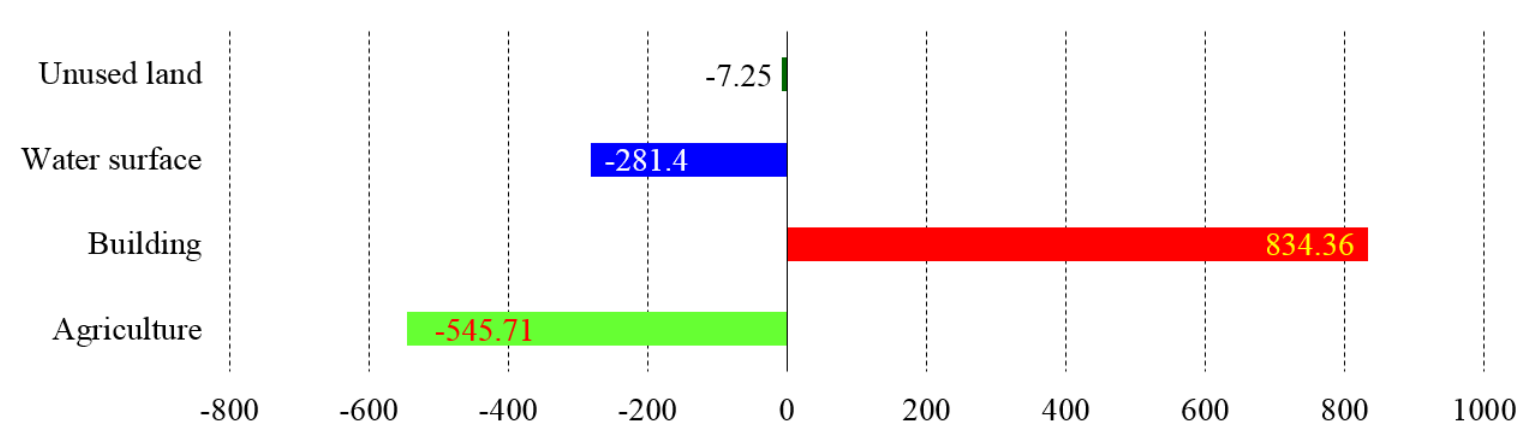

Figure 10: Changes in land use over 2006 - 2014. Sources: own study.

\section{Forecasting of land use change}

Forecasting the changes in land use will based on the volatile proportion of transferring from other types of land use into urban land. Based on the results of volatility in the types of land use in Table 7, the authors determined the percentage change in Table 8.

Table 8

Proportion of land use change in the period 2006 - 2014

\begin{tabular}{lllll}
\hline Land use type & Agriculture & Building & Water surface & Unused land \\
\hline Agriculture & 0.96 & 0.03 & 0.01 & 0 \\
\hline Building & 0 & 1 & 0 & 0 \\
\hline Water surface & 0.06 & 0.13 & 0.81 & 0 \\
\hline Unused land & 0.01 & 0.02 & 0.01 & 0.97 \\
\hline
\end{tabular}

Sources: own study.

In order to predict changes in the future of land use by the Markov Chain, we multiply 2 matrices, i.e. the matrix of land use in 2014 by the matrix of change rate in the period 2006 - 2014 (Table 8).

\begin{tabular}{|l|l|l|l|}
\hline \multicolumn{2}{|l|}{ Current land use in 2014 } \\
\hline Agriculture & Building & $\begin{array}{l}\text { Water } \\
\text { surface }\end{array}$ & $\begin{array}{l}\text { Unused } \\
\text { land }\end{array}$ \\
\hline $15,970.68$ & $5,755.79$ & $2,190.34$ & 211.80 \\
\hline
\end{tabular}$\quad$\begin{tabular}{|l|l|l|l|l|}
\hline 0.96 & 0.03 & 0.01 & 0.00 \\
\hline 0.00 & 1.00 & 0.00 & 0.00 \\
\hline 0.06 & 0.13 & 0.81 & 0.00 \\
\hline 0.01 & 0.02 & 0.01 & 0.97 \\
\hline
\end{tabular}

$=$\begin{tabular}{|l|l|l|l|}
\hline \multicolumn{4}{|l|}{ Future land use in 2022 } \\
\hline Agriculture & Building & Water surface & Unused land \\
\hline $15,430.64$ & $6,535.94$ & $1,957.24$ & 204.79 \\
\hline
\end{tabular}


Similarly, in order to predict the process of land use volatility over the next years, we multiply the land use in the following year by the change rate.

Figure 11 shows that, from 2006 to 2014, the amount of land used for building purposes increased the most, i.e. by 834.36 hectares, while agricultural land, water surfaces and unused land decreased by $545.71 \mathrm{ha}, 281.4$ ha and 7.25 ha respectively. In the forecasts for 2022, building land is expected to reach 6,523.39 hectares, while agricultural land, water surfaces and unused lands are expected to amount to $15,463.27$ ha, $1,936.00$ ha and 205.45 ha respectively. In 2030, the area of building land is forecasted to be 7,243.64 ha, agricultural land - 14,960.81 ha, water surfaces - 1,724.87 ha, and unused land - 199.29 hectares (Table 9 and Figure 11).

Forecast of land use change up to 2030 (Unit: ha)

Table 9

\begin{tabular}{lllll}
\hline Year & Agriculture & Building & Water surface & Unused land \\
\hline $\mathbf{2 0 0 6}$ & $16,516.39$ & $4,921.43$ & $2,471.74$ & 219.05 \\
\hline $\mathbf{2 0 1 4}$ & $15,970.68$ & $5,755.79$ & $2,190.34$ & 211.80 \\
\hline $\mathbf{2 0 2 2}$ & $15,430.64$ & $6,535.94$ & $1,957.24$ & 204.79 \\
\hline $\mathbf{2 0 3 0}$ & $14,899.02$ & $7,268.51$ & $1,763.08$ & 198.01 \\
\hline
\end{tabular}

Sources: own study.

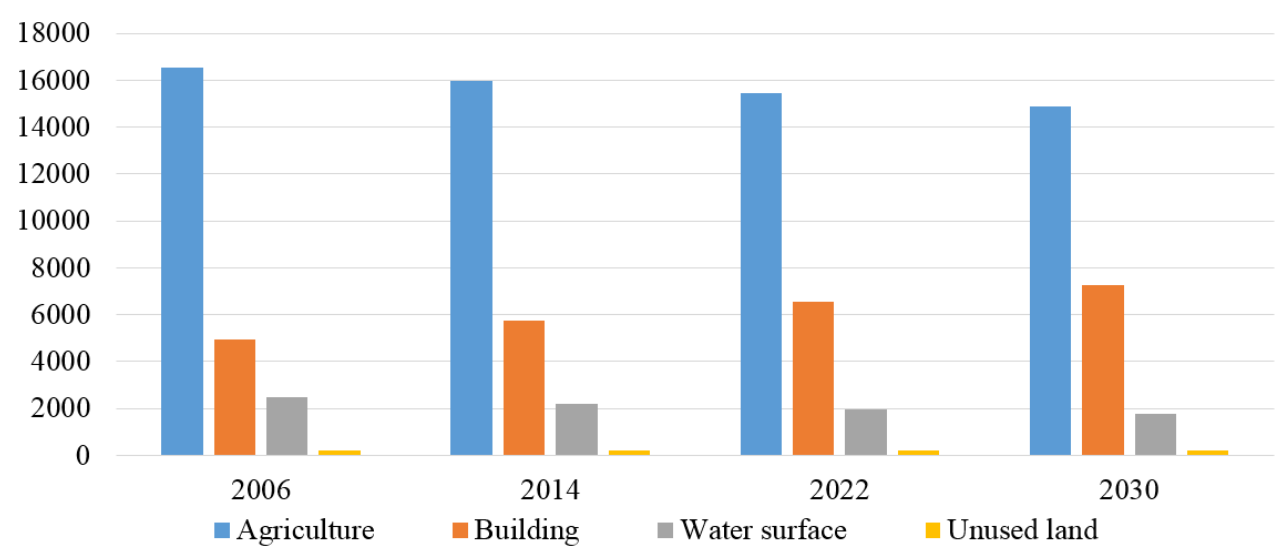

Fig. 11. Forecasted land use change up 2030. Sources: own study.

\section{Conclusion}

Based on images from Landsat 5 in 2006 and Landsat 8 in 2014 of the Y Yen District, we developed a deciphering key for 4 land use types, including agricultural land, building land, water surfaces and unused land as the basis for interpreting remote sensing images.

The results of the deciphering process in the period of 2006 - 2014 showed that the total area of non-agricultural land increased by 834.36 hectares, of which 545.71 hectares of agricultural land changed to non-agricultural land, 281.4 hectares of water surface area changed to non-agricultural land, 7.25 hectares of unused land changed to other types of land use. This change demonstrates an increasing pace of the district's development.

Remote sensing and GIS combined with the Markov Chain when forecasting changes in land use up to the year 2030 did not achieve the highest accuracy; the reason behind this is that land use policies may change in the forecasted time period. The Markov Chain is an appropriate choice in cases where there is no change in policies in the period covered by the forecast.

\section{References}

Assian Association on Remote Sensing, 2004, Asian Conference on Remote Sensing, 11-2004, Proceeding $1,2$.

CHUVIECO E., 2016, Fundamentals of Satellite Remote Sensing: An Environmental Approach, Second Edition, CRC Press, pp. 98-107.

Crosetto M., Mroz M., 1998, Optical-Radar Data Fusion for Land Use Classification, Proceedings of the ISPRS - Comm, VII International Symposium ECO BP, Budapest, Hungary 1-4 sept, Int. Arch. Phot. and RS, Vol. XXXII., Part 7, pp. 698-705. 
JOHN R.JENSEN, 1996, Introductory Digital Image Processing.

KASPER KOK, MANUEL WINOGRAD 2002, Modelling Land-use Change for Central America, with Special Reference to the Impact of Hurricane Mitch, Ecological Modelling, 149, 53-69.

Mróz M., 2002, Radiometric and Textural Fusion of Multiresolution Landsat 7 ETM+ Channels for Improvement of Visual Image Interpretation and Land Cover Classification, In the Proceedings of the 22nd Symposium of the European Association of Remote Sensing Laboratories (EARSeL), Prague, Czech Republic, 4-6 June 2002, "Geoinformation for European-wide Integration”, Editor Thomas Benes, ISBN 90 77017712, pp. 251-258.

Nguyen K.T., Pham V.T., Tran Q.V., Nguyen T.T.H., 2011, Curriculum on Remote Sensing, Hanoi University of Agriculture Publishing House.

NorRIS, J.R., 1998, Markov Chains, Cambridge University Press.

RicHARDS, J.A, 1999, Remote Sensing Digital Image Analysis, Springer-Verlag, Berlin, p. 240.

ROBERT GILMORE PONTIUS, SILVIA H.PETROVA, 2010, Assessing a Predictive Model of Land Change Using Incertain data, Environmental Modelling and Software, Vol. 25, pp. 299-309.

DEEPARK K.RAY, BRYAN C.PIJANOWSKI, 2010, A Backcast Land Use Change Model to Generate Past Land Use Maps: Application and Validation At the Muskegon River Watershed of Michigan, USA, Journal of Land Use Science, 5(1), pp. 1-29.

SOHL, T.L., SAYLER, 2008, Using the FORE-SCEM Model to Project Land-Cover Change in the Southeastern United States, Ecological Modelling, Vol. 219, pp. 49-65.

SOHL, T.L., SAYLER, K.L., DruMMOND, M.A., LOVELAND, 2007, The FORE-SCE Model: A Practical Approach for Projecting Land Cover Change Using Scenario-Based Modeling, Journal of Land Use Science, 2(2), pp. 103-126.

VogelmanN, J.E., TOLK, B., ZHU 2009, Monitoring Forest Changes in the Southwestern United States using Multitemporal Landsat data, Remote Sensing of Environment, Vol. 113, pp. 1739-1748.

WANG, Y., Mitchell, B.R., NugranAD-MARZILLI, J., BONYNGE, ZHOU, Y., SHRIVER, 2009, Remote Sensing of Land-Cover Change and Landscape Context of the National Parks: A CaseSstudy of the Northeast Temperate Network, Remote Sensing of Environment, Vol. 13, pp. 1453-1461. 